\title{
The Character Education Value Learning: The Moses Story Perspective
}

\author{
Romdani, Yumna Rasyid, Aceng Rahmat \\ \{ Ibnuarafat1@gmail.com ${ }^{1}$, yumna.rasyid@unj.ac.id ${ }^{2}, \underline{\text { Aceng57@ gmail.com }^{3}}$ \} \\ Language Education, Postgraduate of State University Jakarta, Jakarta, Indonesia ${ }^{1,2,3}$
}

\begin{abstract}
The aim of this study is to get the comprehension of Moses story in every letter in the Qur'an that tells the story of Moses in terms of analyzing the character education values. The method used qualitative descriptive through content analysis method. The data is taken from the Quranic verses that have the story of Moses using Roland's denotation meaning theory. The data validity used credibility, transferability, dependability, confirmability. Data analysis are a process of data reduction, data presentation and conclusion. Findings are the values of character education are character education based on religion, culture, and self-potential.
\end{abstract}

Keywords: Al-Quran, Moses Story, Character Education, Value

\section{Introduction}

In general, the stories in the Quran aim to explain the principles of delivering the message and explain the principles of the Shari'a brought by the Prophets. It strengthen the belief of people about their victory and its supporters and the destruction of evil and its defenders, justifying the earlier Prophets, reviving memories of them and perpetuating their traces and legacies, revealing the truth of Muhammad in his preaching with what he preached about matters concerning the previous people throughout the period and generation, revealing the lies of the scribes with the arguments that reveal their inadequacies and clues, and challenge them with the contents of their own books before the book is changed and replaced, one form of literature that can attract the attention of the listeners and establish the messages contained within it [1]. It is found a number of objectives of the exposure of the story in the AL-Qur'an: 1. Pushing the human mind to keep asking and seeking the real truth. 2. Communicating the knots of human experience in the form of a valuable lesson for mankind. 3. Setting aside negligence and forgetting of the self. 4. Delivering arguments about the science of God covering the whole movement of history past, present, and future, 5. Strengthening the argument about the concept of a single truth as carried by the entire mission of the sky [2].

The story of al-Qur'an, both in terms of themes, narratives, characterizations, distribution, and language style is a da'wah media that is used to influence the emotions and thoughts of the reader through the beauty of the art of language. So important is the story in conveying God's ideas that it gets a third of the contents of the Qur'an. In fact, many letters are named according to the content of the stories contained in them, such as the letter of Yusuf, Noah, alQashash and so on. Of all the verses of the Qur'an, there are 35 letters containing stories, and most are long letters. 
Based on the description above, the study of the story of the Qur'an is not enough just to read and translate, study and read the interpretation. Instead, it must be followed by conducting an analytical study to be able to identify the style of language used in the Quran so that it can provide a deeper understanding and can influence the emotional aspects. Through the study of the style of the Quran, the language will be known the secret behind the variation in the exposure of the stories of the Qur'an.

One of the stories repeated repeatedly in the al-Qur'an is the story of Moses, both of which are presented at length or only at a glance. The story of Moses in the Qur'an is presented in 35 letters and is spread in 130 verses either in the letters Makkiyah or letters revealed under the prophet were still in Mecca, or Madaniyah when the prophet had migrated to Medina. At the time of the apostle, the story of Moses was read according to the culture of the 7th-century Arab society in a situation where the prophet was psychologically under pressure, besides politically and socially the pressure of the Meccan polytheists was increasingly massive and violent. In this condition the story of Moses was read and repeated in several letters, giving rise to a certain meaning. Briefly, from the results of his interpretation of the story, we know that the apostle then returned steadfast in preaching, firm in his faith, even some of his crucial policies were born such as orders to migrate and send da'i out of Mecca.

There have been several previous studies that have made the Quran source of its research, both related to the theme, style of language, and values of character education. For researchers who work as teaching staff in language education, this research is very useful because it can improve the ability of researchers and students in the study of story themes in the Qur'an and can improve the ability to analyze a story to get a message that can be used as a medium for learning character education. Because the process of student character formation is not only taken from rigidly taught theories. But through the stories in the Quran will be more interesting to understand. As we know that examples are events that are easily accepted by students and can be applied in everyday life. Moreover, the story comes from the Al-Quran which has become a believer in the life of Muslim people.

Statement of Problem

Based on the problem above, the formulation of the problem in this research as follows; What character education values are found in the story of Moses in the Qur'an based on the denotation of Roland Barthes?

\section{Literature Review}

\subsection{Character Education}

Character education is a national movement creating schools that foster ethical, responsible and caring young people by modelling and teaching good character through an emphasis on universal values that we all share [3]. The same thing expressed by Lickona in Munir, which defines character education is education to shape a person's personality through character education, the results of which are seen in a person's real actions, namely good behavior, honesty, responsibility, respect for the rights of others, hard work, etc [4]. Elkind and Sweet in Lickona said that "Character education is the official deliberate to help people understand, care about, and act upon core ethical values. When we think about what we want for our children, it is clear that we want them to be able to judge what is right, care deeply 
about what is right, and then do what they believe to be right, even in the face of pressure from without and temptation from within [5]. Thus character education is a conscious and earnest effort by a teacher to teach values to his students. Character education is the process of giving guidance to students to become whole people with character in the dimensions of heart, mind, body, and taste and intention. Character education can be interpreted as value education, moral education, character education, character education that aims to develop the ability of students to be able to make good decisions, maintain what is good, and realize that good in everyday life with all their heart.

\subsection{Character Education Value}

The Ministry of National Education has formulated 18 Character Values that will be embedded in students as an effort to build the nation's character. Following are 18 Values in Character Education, version of the Ministry of National Education: [6]

1. Religious, namely obedience and persistence in understanding and carrying out religious teachings (belief streams) adopted, including in this case a tolerant attitude towards the implementation of other religious services (belief streams), and living in harmony and side by side.

2. Honest, namely attitudes and behaviours that reflect the unity between knowledge, words and deeds (knowing what is right, saying the truth, and doing what is right) so as to make the person as a person who can be trusted.

3. Tolerance, namely attitudes and behaviours that reflect respect for differences in religion, the flow of beliefs, ethnicity, customs, language, race, ethnicity, opinions, and other things that are different from themselves consciously and openly, and can live quietly in the middle the difference.

4. Discipline, namely habits and actions that are consistent with all forms of regulations or rules that apply.

5. Hard work, namely behaviour that shows earnest effort (fighting to the last drop of blood) in completing various tasks, problems, jobs, and others as well as possible.

6. Creative, namely attitudes and behaviours that reflect innovation in various aspects of solving problems, so that they always find new ways, even new results that are better than before.

7. Independent, namely attitudes and behaviours that are not dependent on others in completing various tasks and problems. However, it does not mean that is not permissible to collaborate collaboratively, but not to throw tasks and responsibilities to others.

8. Democratic, namely the attitude and way of thinking that reflects equality of rights and obligations fairly and evenly between himself and others.

9. Curiosity, namely ways of thinking, attitudes, and behaviours that reflect curiosity and curiosity about everything that is seen, heard and studied more deeply.

10. Nationalism, namely attitudes and actions that place the interests of the nation and state above personal or individual interests and groups.

11. Love of the homeland, namely attitudes and behaviours that reflect a sense of pride, loyalty, caring, and high appreciation for language, culture, economy, politics, and so on. So that it is not easy to accept the offer of other nations that can harm the nation itself.

12. Appreciate achievement, namely an open attitude towards the achievements of others and acknowledge their own shortcomings without reducing the spirit of higher achievement.

13. Communicative, friendly or proactive, namely attitudes and open actions towards others through polite communication so as to create collaborative cooperation well. 
14. Peaceful love, namely attitudes and behaviour that reflects the atmosphere of peace, security, calm, and comfort in the presence of himself in a particular community or community.

15. Love to read, which is a habit with no compulsion to provide time specifically to read a variety of information, both books, journals, magazines, newspapers, and so on, giving rise to policies for him

16. Care for the environment, namely the attitudes and actions that always strive to preserve and preserve the surrounding environment.

17. Social care, namely attitudes and actions that reflect concern for others and the people who need them.

18. Responsibility, namely the attitude and behaviour of a person in carrying out their duties and obligations, both relating to themselves, social, community, nation, state, and religion.

Based on the explanation above, it can be concluded that individuals who have character values are individuals who try to do the best things for God, themselves, others, the environment, nation and state and the international world in general by optimizing the potential (knowledge) of themselves and accompanied by awareness, emotions, and motivations (feelings), and has values such as trust, faith, devotion, hard work, discipline, honesty, tolerance, careful, smart, dynamic, persistent, frugal, empathetic, wise, straightforward, assertive, thinking far ahead, thinking mature, responsible, strong-willed, good thought, forgiving, generous, fair, respectful, devoted, self-control, commitment, independent, introspective, sincere, patient, shy, diligent, friendly, willing sacrifice, humble, sportive, respectful, orderly, productive, moral, diligent, tough, right on the promise, tenacious so that the character of the nation is identical with the character of the nation or the character of the nation. A nation with character is a nation that has morals and virtues, on the contrary, a nation that has no character is a nation that is not or less moral or does not have.

In determining the value of character education in the story of Moses in the Quran, the researcher uses Roland Barthes' semiotic approach which develops ideas from Saussure. The core of Barthes's theory is the idea of two orders of significations. The first sign order describes the relation between the signifier and the sign in the sign, and the sign with the referent in the external reality. Barthes calls it a denotation, namely the real meaning of the sign. The second stage signification is often called connotation, describing interactions that occur when the sign meets the feelings or emotions of the reader and the values of the culture [7].

\section{Methodology}

\subsection{Methods and Procedure}

The method this study is a qualitative descriptive study that used the content analysis. Content analysis is an in-depth analysis that can use both quantitative and qualitative techniques for messages using scientific methods and is not limited to the types of variables that can be measured or the context in which messages are created or presented [8]. 


\subsection{The process of Collecting Data}

The process of collecting data used documentation that is taken from some letter and verses of Al-Quran. The steps in collecting data are: read the verses Al-Quran that has a story of Moses, assign the theme of the story of Moses in a letter, and determines the values of character education that can be drawn from the verses of the story of Moses in the Qur'an. The instrument of this research is the researcher itself according to qualitative research characteristic.

\subsection{The technique of Data Analysis}

The research analysis can be described in a tabular form. The data analysis procedure used theory from Sugiyono [2] which mentions, there are three stages that must be passed to facilitate the data analysis, i.e data reduction, data presentation, and the conclusion or verification of data [9] While the validity of data among others; credibility, transferability, dependability, and conformability.

\section{Finding}

Following is the table of finding data that used to analyze the education character learning from the Moses story;

Table 1. Quranic Verses of Moses Story Contains a Message of Character Education Value

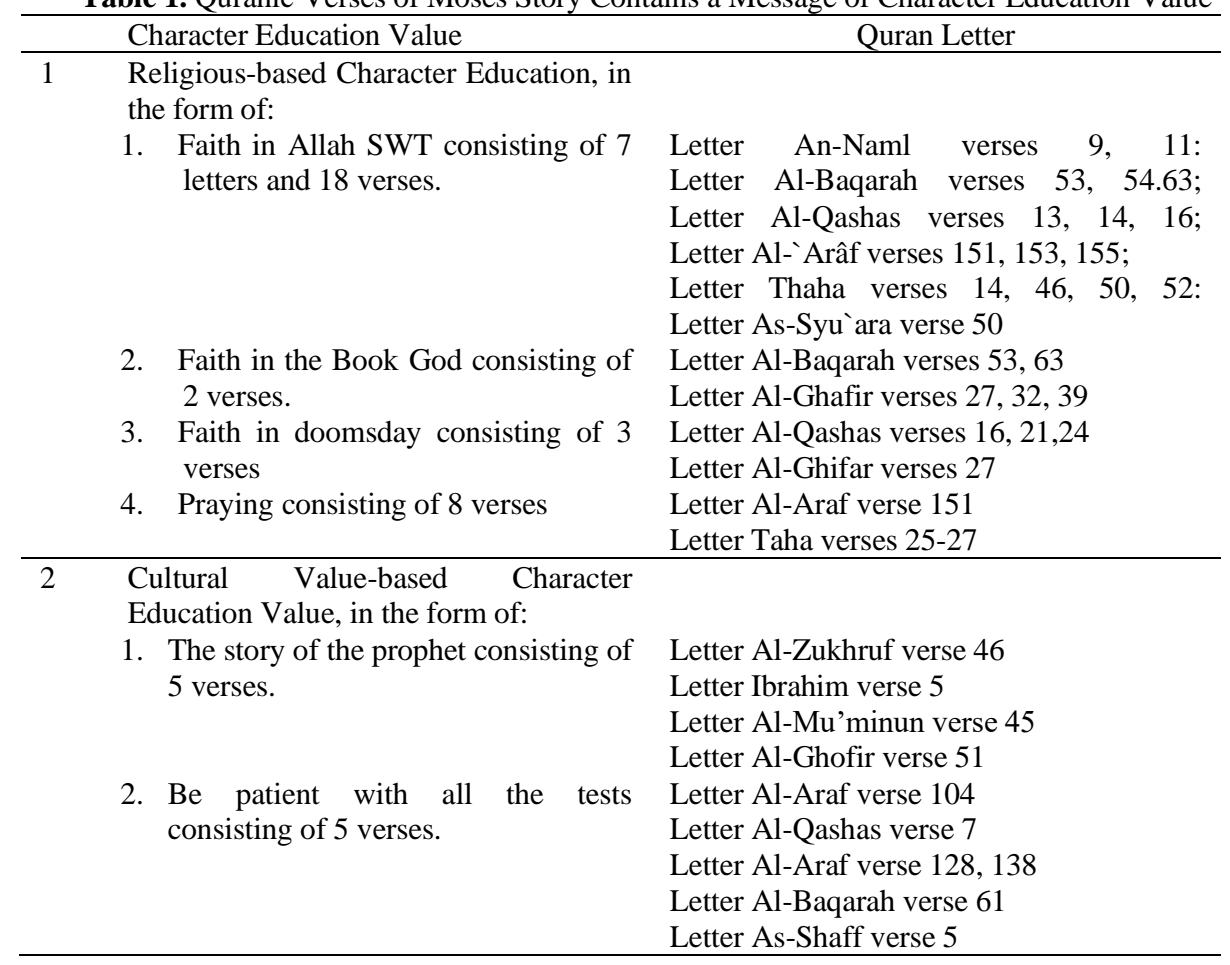




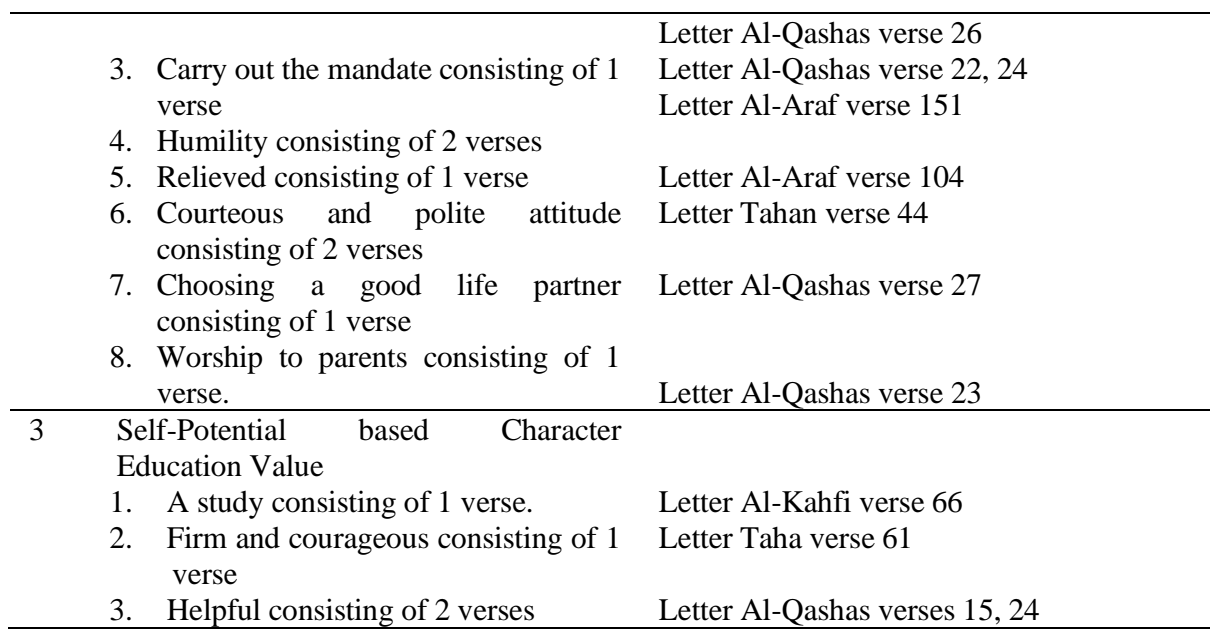

The character education value learning can be learnt through some letter in Moses story. It is as media of learning in the class. Because the Quran has almost of knowledge that is needed by a human. In the class, the teacher is available to use it as media of learning to deliver character education value.

\section{Discussion}

Conveying the invitation to believe in Allah SWT is the main task of the prophets. In the story of Prophet Moses, there are many verses that contain the value of faith education in God. The values are one of the character education that must be had by everyone. These values can be expressed from the sentences or dialogues that occur in the story, can also be revealed in the storyline itself. The letter and verses that has these values are; An-Naml verses 9, 11; letter Al-Baqarah verses 53, 54.63; letter Al-Qashas verses 13, 14, 16; Letter Al-`Arâf verses 151, 153, 155; letter Thaha verses 14, 46, 50, 52: letter As-Syu ara verse 50. From that letter and verses, we can be concluded that each one has the belief in the God. It can be a bastion of self in behaving.

God commands someone to carry out prayers and always remember Him. The nature of God Almighty is the most absolute characteristic of God. If God is numbered, then God loses his power, because he still needs help from others. If God is numbered and with their own will. Then there will be chaos in its creation. God states about His omnipotent Essence without favouritism. God gives life to all his creatures. All get God's love and the recipient of repentance for anyone who makes a mistake, if he realizes his mistake, then regrets his mistake, asks forgiveness from Him, and promises not to repeat it.

The verse states about the power of God to give guidance to those who want it. It must be coveted by humans to get it and must be picked up by his presence. It's not just sitting stunned waiting for guidance from the sky. To pick up guidance, one can do it by studying and charity. On the other hand, even though someone has tried their best to get the guidance, but God still has the power not to give it. There is no single creature that can prevent God from giving guidance to someone. It's just that God himself declared that He expected His Substance to do wrong to His servant. 
In the story of Moses in the al-Qur'an found verses that contain information about faith in the book of God, there are in his body in Q.S al-Baqarah verse 53:

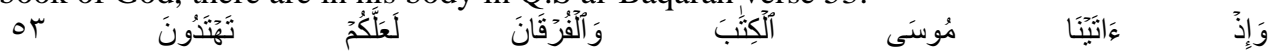

"And (remember), when We gave to Moses the Book (the Torah) and the information that distinguishes between right and wrong, so that you may receive instructions".

In the above verse, it is stated that Moses got the Torah which served as a guide for his people, the children of Israel. The book contains the rules and laws of God that must be obeyed by the children of Israel, as in Q.S al-Baqarah verse 63.

When the children of Israel refused to implement the content of the book of the law, and do not cling to him, God commands the angels to lift up the mountain Thur to their heads and threatened to drop it into their heads. Then, they submit and bow down, a sign that they were willing to practice it. They are said to prostrate themselves while holding their heads to the mountain for fear that the mountain will be inflicted on them. That is why - as told by Sya'rawi - until now the method of prostration by the Jews is by pointing the face downward, and the other side looking upwards [10].

The story of Moses reminds the value of faith to the final day, as in Q.S al-Ghâfir verse

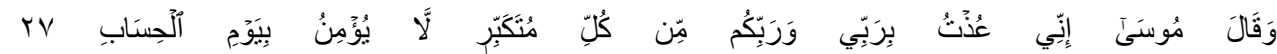
"And Moses said:" Verily I take refuge in my Lord and your Lord from every person who boasts that does not believe in the Day of Reckoning.

The verse above tells how Moses had strong faith in the final day. The previous verse tells the desire of Pharaoh to kill Moses. The above verse is the answer of Moses when he hears Pharaoh's plan to kill him. The mention words "yaumil hisab" which means the day of reckoning or the Day of Judgment juxtaposed with the nature of the pride of Pharaoh, because the pride of Pharaoh who felt he had power caused him to not trust the day of reckoning.

The value of faith in the final day is also found in the story of the presence of Fir'aun's prince, who believed in Moses. When he reminded his people that the life of this world was a temporary pleasure, as in Q.S al-Ghâfir verse 39:

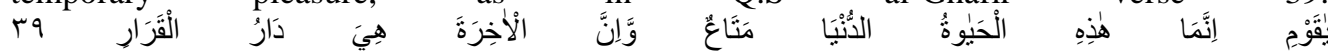
"O my people! Surely the life of this world is only (temporary) pleasure and indeed the Hereafter is the eternal land."

In the verse above the last day is called "darul qarar" which means eternal land, because in the Hereafter Allah will give eternal life, so try to get happiness in that eternal life, not the other way around. In Q.S al-Ghâfir verse 32:

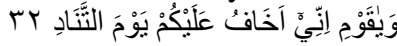

"And O my people! Verily I really worry about you (torture) the day of calling each other,"

In the verse above the final day is called "yaumattanad" which means the day of calling each other, because at that time people will call each other asking for help from others. But the call is in vain because no one can give help to the person who is calling.

In the Qur'an, we find many verses relating to the final day with various names, such as yaumul qiyamah, yaumul jaza ', yaumul hisab and others, containing wisdom so that humans realize that the final day is something that is sure to happen, humans realize that the world is temporary. It is not fitting for someone to only pursue the life of the world and neglect the life he will experience on the final day. The final day is the day of vengeance for every act that has been done in the world. 
Moses was a humble person and always prayed, always pouring out and complaining about all the problems he faced, asking for guidance, help and forgiveness from God. Like when Moses did the mistake of killing a Qibty, Moses prayed in Q.S al-Qasshash verse 16:

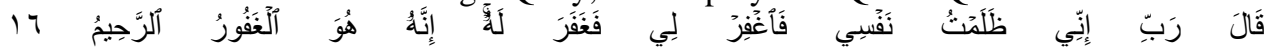
"Moses prayed:" My Lord, indeed I have persecuted myself because of that forgive me ". Allah forgives him, verily Allah is the One who is Forgiving, the Most Merciful.

The verse above tells us that Moses realized his mistake and regretted it, then he narrowed his regret by asking forgiveness from a mistake that was not intentional by him. Moses offered a prayer full of confidence and optimism that his prayer was granted by God.

A good person is not a person who has never sinned, because every human being must have sinned. But the best people who sin are people who realize their mistakes, regret them, and ask forgiveness from Allah, and with optimism that prayer will be granted by Allah.

In another verse Moses prays, as in Q.S. al-Ghâfir verse 27

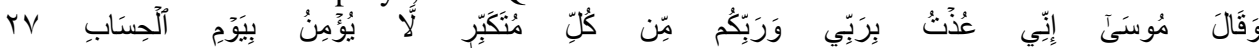
"And Moses said:" Verily I take refuge in my Lord and your Lord from every person who boasts that does not believe in the Day of Reckoning.

The verse above reveals how Moses steadily begged Allah for help when he received death threats from Pharaoh. The threat does not make him tremble and fear, even makes it more stable to always give everything to Allah SWT.

In another verse Moses prays, as in Q.S. al-Qashas verse 24:

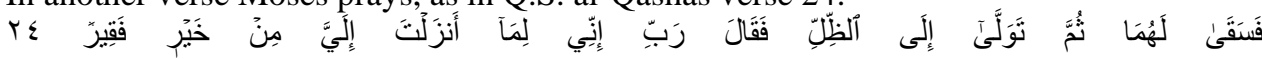
"So Moses gave the animal a drink to (help) both of them, then he returned to the shady place and then prayed:" My Lord, indeed I really need something good that you have sent me down ".

The verse above tells of the attitude of Moses who always gave all his affairs to Allah and was in desperate need of Allah's help. The attitude above illustrates how Moses has a soul that is always connected with God. Whatever joy he gains, and whatever difficulties he faces, Moses always makes God the place to lean.

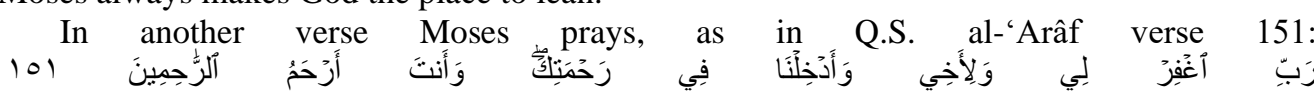
"Moses prayed:" My Lord, forgive me and my brother and put us in the mercy of You, and You are the Most Merciful of the Merciful. "

The above verse tells Moses who was aware after being carried away by emotion to Aaron who was helpless against the iniquity of his people who returned to sin by worshiping the calf idols they made themselves. Moses realized that it was not a mistake and Aaron did not want it. Moses prayed for himself and for Aaron to be always covered by the grace of God in the totality of his life.

In another verse Moses prays, as in Q.S. Taha verses 25-27:

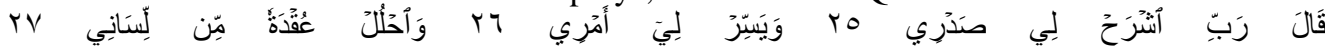
"Said Moses:" My Lord, spread to me my chest, "and make it easy for me for my business", "and release the stiffness of my tongue".

The verse above tells how Moses was aware of his very heavy duty to preach to the tyrant Pharaoh. So he begged Allah for help to get the soul spacious in the face of all difficulties in preaching so that it made things easy, and he could deliver his da'wah freely without a burden so that it could be understood by the object of his preaching.

The apostolic story of Moses mentioned in the Qur'an contains a lot of wisdom. Ibn Taymiyyah said that the story of Moses shows the contradiction of two extreme things, namely between the right and the false, where Pharaoh is a very extreme picture of ignorance, 
because he did not believe in Moses and God at once, while Moses was the ultimate picture of faith, because he can move directly to God and get prophetic treatise assignments also directly from God without the intermediary of angels [11].

Ibn al-Qoyyim explained among the reasons that the number of the stories of Moses mentioned in the Quran was due to the similarities with the life of the prophet Muhammad who faced many tests and challenges. So Muhammad said when various trials came to him: "Indeed, Moses was given a more severe test than this, and Moses was patient" [12]. In carrying out their preaching every prophet always gets resistance from his people. For this reason, the prophets must be patient in facing various kinds of tests and trials. No exception what was experienced by Moses, he faced various tests and trials of various kinds, even since Moses was born, he had to be carried away to the river by his mother to be saved from the murders carried out by Pharaoh. It is told by Allah SWT in the letter of al-Qasshash verse 7. The story told that every student has to build their character as patient people in finishing their study. They have to make a good commitment to getting the future. Because Moses has a good patient in studying.

Moses was one of the apostles who received the gift from Allah, which is a gift that was not given by God to other prophets, such as the miracles that God gave to Moses. However, Moses still has the spirit to keep increasing his knowledge. When meeting Khidir, Moses asked Khidir to accept him as a student who accompanied him on his journey. This is found in Q.S. al-Kahf verse 66:

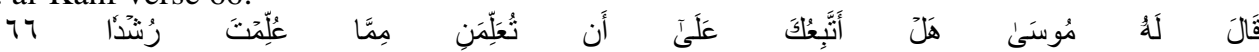
"Moses said to Khidir:" May I follow you so that you teach me the true knowledge among the sciences that have been taught to you?

The story of Moses and Khidir is told in Al-Kahf 60-82. In the story contains many values that can be learned by educators and scholars, including:

1. Have high determination and passion to always improve self-quality. As a prophet who served as an educator, Moses had a high spirit to keep studying. Even Moses made a long and tiring journey with Khidir solely to gain knowledge.

2. Always feel like you have a lack of knowledge, don't feel that he's the smartest. Moses got a rebuke from Allah SWT because he had thought that he was the smartest.

3. In studying, preparation and supplies are needed, both in the form of determination and burning passion, as well as preparation and material provisions. When studying with Khidir, Moses prepared well the things needed in studying, such as logistics supplies in the form of fish caught by him.

4. Realizing the lack and mistakes, apologizing, and ready to accept the risk due to mistakes made. In the course of studying with Khidir, Musa was able to deny the promise he had made so that he would not comment on everything that happened when he was studying. Because of this defeat, Moses apologized to Khidir. as a teacher, Khidir also forgives all the mistakes made by Moses. But the third time, when Moses made a mistake repeatedly, Khidir gave punishment to Moses not to follow him again.

The explanation has given a new perspective that in character education value learning is not only using formal learning, but also the educator can put it in other subject learning like as in literacy learning. Such as done in Moses story learning, we can explore the message from the story to build students' character education value. Many types of research that have done by the researcher, like as Halim [13] discussed how the Qur'an uses stories in introducing message and values by focusing on the story of Prophet Yusuf A.S in Yusuf; Naqvi's research is the commencement of character education: a religious perspective [14]. This research 
explores the elements of character, using religious texts, which need to be included in the curriculum so that students can get out of negative thinking. The study proves that character education starts from the beginning of civilization. This study has important meaning for future studies in the field of character education and religious studies.

The same research was carried out by Kabir [15] explored about Qur'ānic Approach to the Inculcation of Moral Values. Moral education has long been an important and intrinsic learning goal. Schools aim not only to make people smart but also to make them good citizens and ready to apply moral values. However, with the increasing rate of change in the world today, the goal of moral education has been developed into the background because the demand for capitalist markets has influenced mainly the development of skilled individuals who are philosophically ready to fill the gaps in the job market. As a result, moral values have been lost even by Islamic education teachers, and when taught, are often not in accordance with the nature and objectives of Islamic education. Thus, the teaching of Islamic education in schools cannot achieve its objectives, mainly because of the lack of effective approaches and methodologies of the Quran when teaching moral values. This study explores the approach used by the Qur'an and in its historical narrative in instilling moral values. This includes storytelling, modelling, practical demonstrations, teaching methods, question and answer methods, conversation and dialogue, repetition, and practical demonstrations. The aim is to examine how this approach can be integrated into teacher education regarding moral values.

The equation of this study is to examine the values of moral education that will integrate into character education through the Moses story. Because character education also aims to help moral students. While the difference is that the research being carried out only focuses on the verses about the story of Moses in exploring character values. Like as in Halim research. He used the Quranic stories in introducing messages and values using Prophet Yusuf [16]. The research conducted by Burhanuddin was entitled "Rhetorical Analysis of Leadership and Social Influence in Saha Thaha." The letter of Thaha study will focus on the rhetorical analysis of the verses about the role of a person to be a leader between family, peer groups, society and government. This is also influenced by the support and roles played by other members around it. This will emphasize the symmetrical arrangement of Surah Thaha, who contributes, to understand that the Quranic chapter rhetorically handles the causes and consequences of being a leader. In the end, this research will suggest 'Aqidah and Tarbiyyah as the main and sustainable basis of leadership obtained from this Surah [17].

\section{Conclusion}

Character education values contained in the verses of the story of Moses. There are three aspects of character education value. Those are religious based character education value; cultural based character education value; and self-potential based character education value. These are in 11 letters and 62 verses. In an effort to educate the community, it is time to make efforts to educate the public to become accustomed to animating and living the teachings of their religion. Considering that, most Muslims think that these stories are historical stories, which only serve to convey historical information. As long as the paradigm of the ummah is still like that, it will be difficult to direct them to Islamic teachings that are functional and contextual. A paradigm shift must be made in an effort to functionalize the meaning of the stories in life. In order to socialize the new paradigm of reading al-Qur'an stories, students should be motivated to study and examine the stories. Among the methods to sharpen Islamic 
reasoning and appreciation of religious teachings, is the teaching of al-Qur'an stories that refer to the effort to functionalize God's teachings in life. For that the teaching of al-Qur' stories in mosques and various other places with regard to the theme of the story, verse or letter must be intensified. The story learned has an impact on the learning process of character education values. These values become an important part of building good and polite behaviour and social attitudes. Formal education institutions, it has been mandated for teachers to be able to build the value of student character education. One of the media that can be used is the story of the Quran has been applied to the Arabic education study program at Jakarta State University. Therefore, the results of this study provide recommendations to teachers, especially in the Arabic education study program in order to use the stories in the Qur'an as a medium for teaching the value of character education. Besides the story of the prophet Musa, many other prophet stories can be used in class.

\section{References}

[1] Khalil al-qattan, Manna. Studi Ilmu-Ilmu Al-Qur`an Bogor: Pustaka Litera AntarNusa, 2011, p..437.

[2] Santosa, Rochmat Budi. Pragmatic Study of Directive Speech Acts in Stories in Alquran. Australian International Academic Centre, Vol. 7 No.5, 2016, p. 82

[3] Pala, Aynur. The Need For Character Education. International Journal Of Social Sciences And Humanity Studies, Vol.3 No.2, 2011, p.23

[4] Munir, Abdullah. Pendidikan Karakter, Yogyakarta: Pedagogia, 2010. p. 4

[5] Lickona, Thomas. Educating For Character: How Our School Can Teach Respect and Responsibility. New York: Bantam Books, 2014, p. 51

[6] Suyadi, Kementerian Pendidikan Nasional: Strategi Pemebelajaran Pendidikan Karakter. Bandung: Remaja Rosdakarya. 2013, pp. 8-9.

[7] Sobur, Alex. Semiotika Komunikasi. Bandung: Remaja Rosdakrya, 2006, p.128

[8] Emzir,Metode Penelitian Kualitatif Analisis Data, (Jakarta: Rajawali Pers, 2012), h. 283-284

[9] Sugiyono, Metode Penelitian Kuantitatis, Kualitatif, dan R\&D, Bandung: Afabeta, 2010, p. 246

[10] Sihab, Quraisy, Tafsir Misabah. Jakarta: Lentera Hati, 2000. Vol I. p.218

[11] Ibnu Taymiyah, Majmu' Fatawa, Beirut Darrfikr, vol 9, p.12

[12] Ibnul Qayyim, Jala'ul afham, vol 1, p.152

[13] Halim, Asyiqin Ab, Quranic Stories In Introducing Messages And Values: An Analysis On The Story Of Prophet Yusuf A.S, Jurnal Al-Tamaddun Bil, Vol.11 No.2, 2016, pp..215-250.

[14] Naqvi, Syed Mohsin Raza. The Commencement of Character Education: A Religious Perspective, PJERE, Vol. 2, No. 1, 2017, pp. 27-38

[15] Kabir, Asmau Imam Abdul. The Qur'ānic Approach to the Inculcation of Moral Values: Patterns for Teacher Education, QURANIC, International Journal of Quranic Research, Vol.5, Issue. 2, 2013, pp. 15-32

[16] Halim, Asyiqin Ab. Quranic Stories in Introducing Messages and Values: An Analysis on The Story of Prophet Yusuf A.S, Jurnal al-Tamaddun Bil Vol.11 No.2, 2016, pp.59-66

[17] Burhanuddin, Qaziah Fatihah. Rhetorical Analysis Of Leadership And Social Influence In Surah Thaha, AIJLLS, Vol. 1 Issue 2, 2017. 
